\title{
Brittleness Index of High-Rank Coal Reservoir and Its Influencing Factors in Mabidong Block, Qinshui Basin, China
}

\author{
Yixuan Zhang, ${ }^{1,2}$ Yanjun Meng $\mathbb{D}^{1,2}$ Panyun Hao, ${ }^{3}$ Yanjie Shang, ${ }^{4}$ and Xinyu Fu ${ }^{1,2}$ \\ ${ }^{1}$ College of Mining Engineering, Taiyuan University of Technology, Taiyuan 030024, China \\ ${ }^{2}$ Shanxi Key Laboratory of Coal and Coal Measure Gas Geology, Taiyuan 030024, China \\ ${ }^{3}$ No. 213 Laboratory of Shanxi Bureau of Geology and Mineral Resources, Linfen 041000, China \\ ${ }^{4}$ PetroChina Coalbed Methane Co., Ltd., Beijing 100028, China
}

Correspondence should be addressed to Yanjun Meng; mengyanjun15@126.com

Received 26 February 2021; Accepted 22 April 2021; Published 8 May 2021

Academic Editor: Qingquan Liu

Copyright (c) 2021 Yixuan Zhang et al. This is an open access article distributed under the Creative Commons Attribution License, which permits unrestricted use, distribution, and reproduction in any medium, provided the original work is properly cited.

\begin{abstract}
Brittleness index is an important mechanical index to evaluate the fracturability of conventional oil and gas reservoirs. However, the brittleness index of an organic coal reservoir is more complex. In this study, based on array sonic logging and density logging data, coal brittleness index is calculated using an elastic parameter method in the Mabidong coalbed methane (CBM) block in southern Qinshui Basin. In combination with coal-body structure observation, the maceral analysis, and proximate data of coal cores, a comprehensive study of geological influencing factors of coal brittleness index has been carried out. According to coal fragmentation degree, the coal-body structure of coal seams can be divided into primary, cataclastic, and granulate structure. The average interval of brittleness index of primary, cataclastic, and granulate structural coals is $63.3-71.48,73.01-74.85$, and 77.41-82.77, respectively. The results indicate that generally the order of brittleness index is primary structural coal < cataclastic structural coal < granulate structural coal. Young's modulus and the brittleness index have a good positive correlation. Poisson's ratio and the brittleness index are negatively correlated in No. 3 coal seam but are positive correlated in No. 15 coal seam. The vitrinite content is positively correlated with brittleness index, and the inertinite content is negatively correlated. For the primary and cataclastic structure coal, the ash and volatile is positively correlated with the brittleness index. The correlation of brittleness index, macerals, and coal quality parameters in the primary structure coal is better than that of the cataclastic and granulate structure coal. The research results are helpful to guide the coal brittleness index and coal-body structure prediction in fracturing of CBM wells.
\end{abstract}

\section{Introduction}

Brittleness is a key mechanical parameter in the evaluation of hydraulic fracturing and wellbore stability of coal and shale reservoirs [1-3]. Brittleness of coal refers to the irreversible property of coal breaking, which indirectly reflects the complexity of fractures formed after fracturing in coal and is closely related to the difficulty of fracturing in coal reservoir. Brittleness can generally be quantitatively characterized by the brittleness index. The brittleness index can measure the ability of coal to resist fragmentation under pressure, it significantly affects the cutability and coal production rate during coal mining $[2,4]$ and affects the drilling efficiency during the well drilling process [5]. The brittleness index is also the key index to evaluate the fracturability of coal reservoirs $[1,6]$.

Various researchers have devoted to the studies on the evaluation method of rock brittleness [7-14]. There were divergences between researchers on how to determine the brittleness index of rock. The evaluation of rock brittleness was put forward through uniaxial tensile and compressive experiments in 1974 by Hucka and Das [7]. The relationship between rock brittleness and hardness coefficient and fracture toughness, the functional relationship between rock brittleness and rock tensile and compressive strength, were established through mechanical property experiments and tests in succession $[8,9]$. Since the beginning of this century, with the rise of the unconventional oil and gas industry, the 

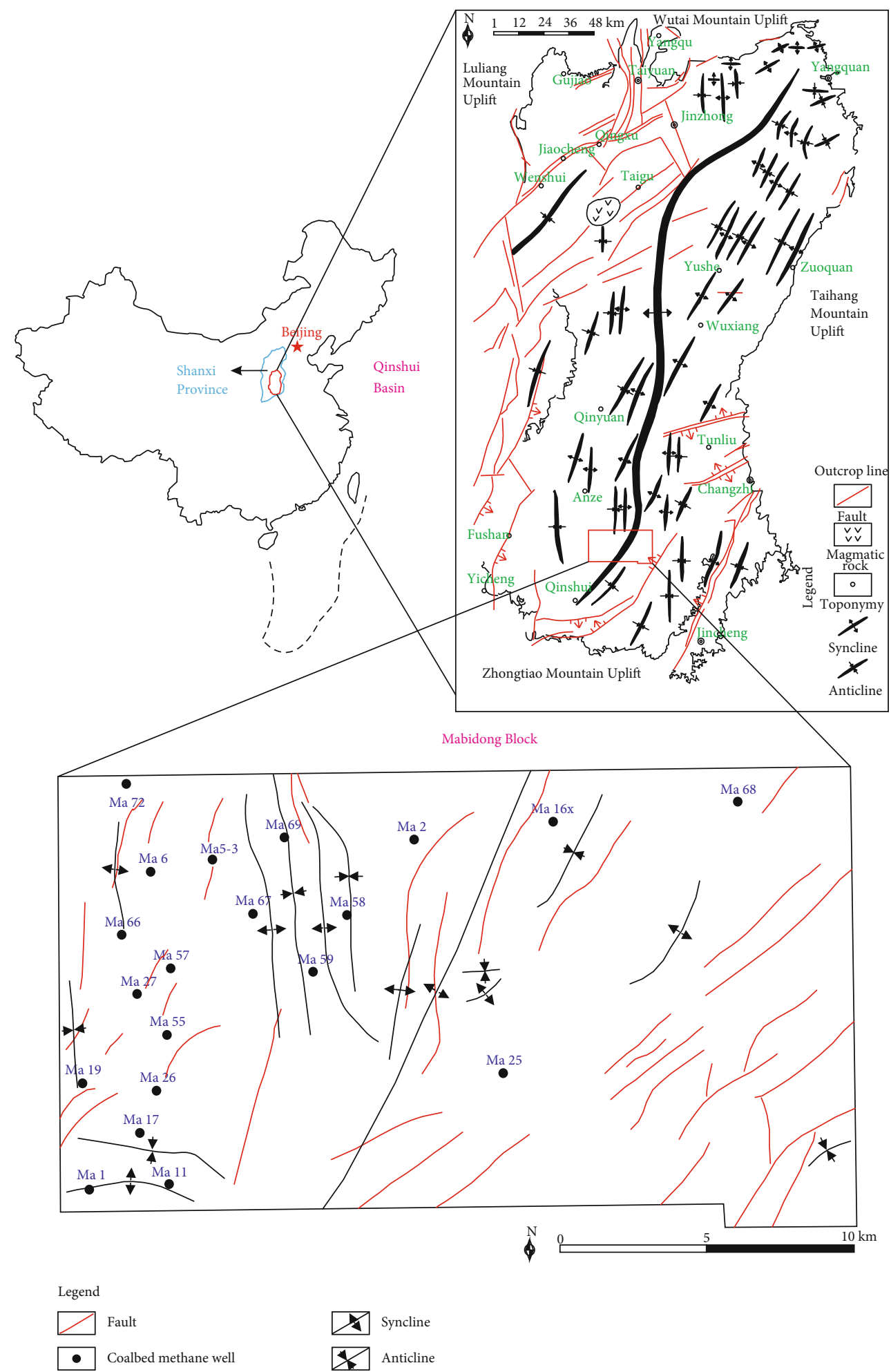

Figure 1: Map of the Mabidong block showing major structures and locations (modified from [20]).

research of brittleness index in coal reservoirs has been widely concerned by scholars. Different researchers summed up the definition of brittleness index and put forward different quantitative calculation methods of the brittleness index. A brittleness index evaluation method based on the rock brittle mineral content was proposed based on the correlation between mineral composition and brittleness in shales [10]. Another method to quantitatively calculate the brittleness index was proposed based on Young's modulus and Poisson's ratio in the rock mechanics parameters [11]. Then, a new method was proposed to evaluate the brittleness of shale by using X-fluorescence element logging data [12]. Some 


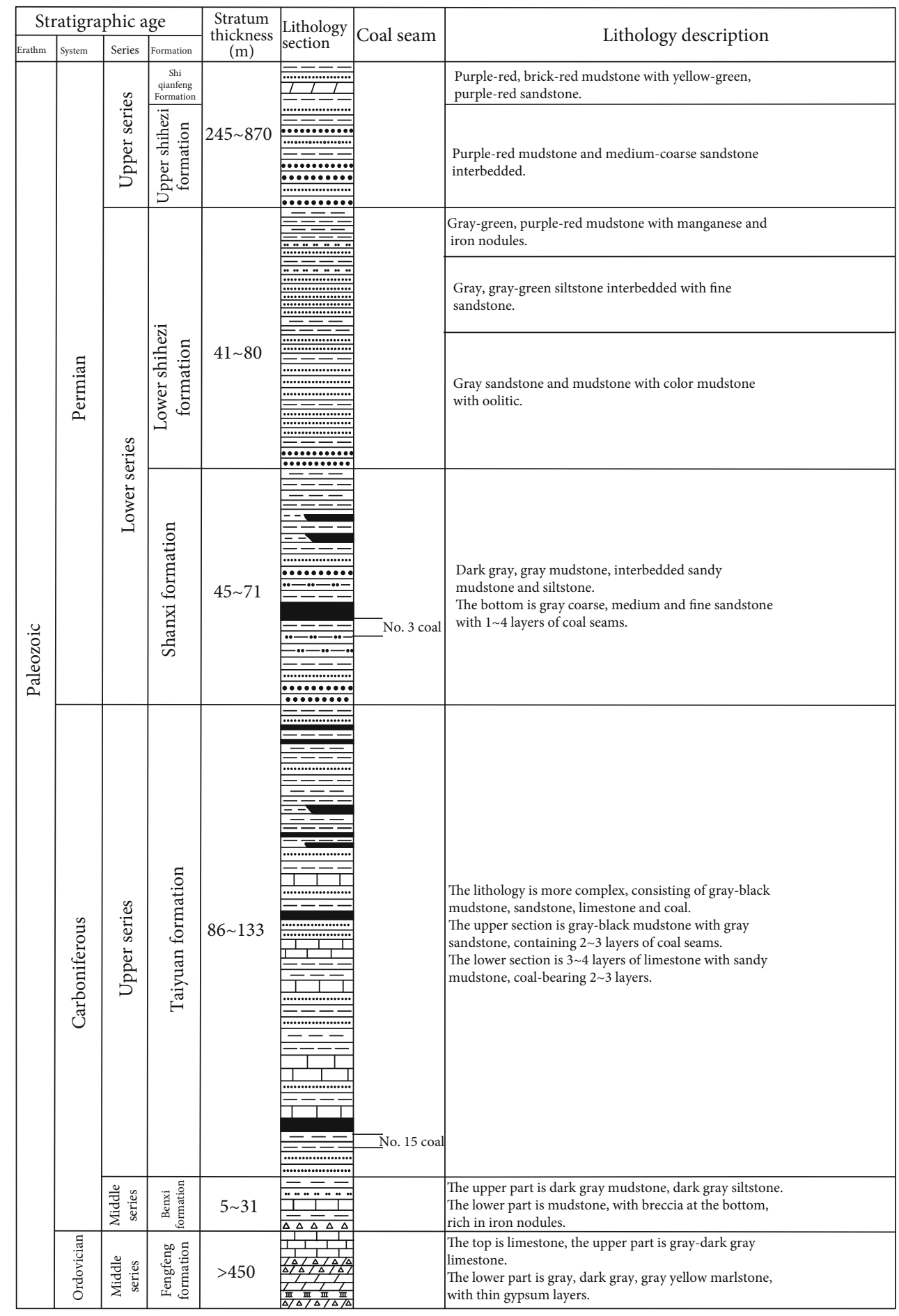

FIGURE 2: Stratigraphic column of coal-bearing sequences in the Mabidong block.

scholars thought that the brittleness index could be quantified from the perspective of influencing factors and coal brittleness evaluation method could be revised from that of shale $[13,14]$. A review of the previous literatures makes it clear that different researchers have different definitions for the concept of rock brittleness.

So far, brittleness index studies have been widely used in shale gas and tight sandstone gas $[1,10-13]$. However, lim- ited by logging technology and the traditional low-cost exploration concept of CBM, there were few researches on the evaluation of brittleness index in coal reservoirs [1518], especially the influence factors of coal brittleness index. Previous studies have shown that the coal brittleness was mainly affected by coal rank, composition, and coal-body structure $[15-17,19]$. However, current scholars are still unclear on the quantitative relationship between coal 
TABLE 1: Coal-body structure division of a coal seam in the Mabidong block (refer to reference [21]).

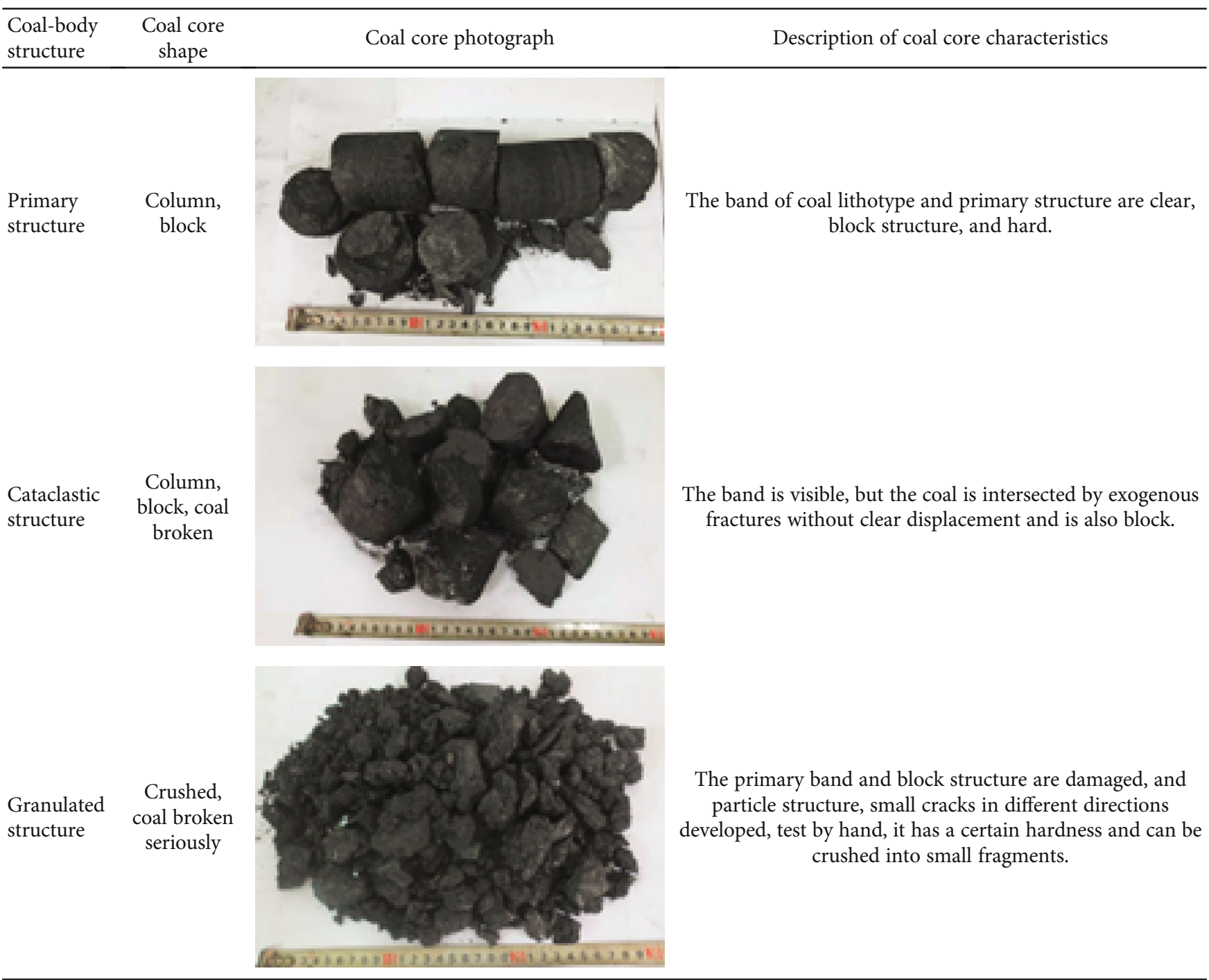

TABLe 2: Coal brittleness index seams with different coal-body structures in the Mabidong block.

\begin{tabular}{lccccc}
\hline Well number/coal seam & Primary structure & Well number/coal seam & Cataclastic structure & Well number/coal seam & Granulated structure \\
\hline Ma 1/No. 3 & $58.18-68.06$ & Ma 69/No. 3 & $71-75.1$ & Ma 11/No. 3 & $79.7-83.4$ \\
Ma 17/No. 3 & $56.6-73.2$ & Ma 1/No. 15 & $76.24-77.13$ & Ma 27/No. 3 & $75.4-84.2$ \\
Ma 58/No. 3 & $61.4-70.9$ & Ma 59/No. 15 & $71.8-72.33$ & Ma 66/No. 3 & $76.5-89$ \\
Ma 67/No. 3 & $62.9-67.9$ & & & Ma 68/No. 3 & $77.09-77.44$ \\
Ma 6/No. 15 & $68.25-75.02$ & & & Ma 58/No. 15 & $75.92-82.4$ \\
Ma 25/No. 15 & $72.58-73.77$ & & & Ma 66/No. 15 & $79.87-80.15$ \\
Average & $63.3-71.48$ & Average & $73.01-74.85$ & Average & $77.41-82.77$ \\
\hline
\end{tabular}

brittleness and inherent influencing factors of coal reservoir. Therefore, the establishment of the coal brittleness index calculation method based on the coal-body structure and composition has important practical significance for brittleness evaluation of coal reservoirs in CBM exploration and development.
In this research, the brittleness index of a high-rank coal reservoir and its influencing factors were studied in Mabidong CBM block, Qinshui Basin, China. Based on the observation and description of coal cores of 15 CBM exploration wells, array sonic logging, density logging, and coal quality test data, the elastic parameter method was used to calculate 
the coal brittleness index reservoirs in this block, and the geological factors on coal brittleness index were analyzed and discussed.

\section{Research Method, Process and Data Source}

2.1. Evaluation Method of Coal Brittleness Index Reservoirs. Coal reservoirs are typical organic reservoirs, so the mineral component method commonly used in shale brittleness index evaluation is unable to be used in evaluation of the coal brittleness index. Therefore, the elastic parameter method was adopted in this study to calculate the brittleness index of high-rank coal reservoir. The calculation of rock brittleness by the elastic parameter method can provide a convenient and practical means for evaluating rock reservoir brittleness by using logging and seismic data $[17,18]$. Rickman et al. first used normalized Young's modulus and Poisson's ratio to characterize rock brittleness [11]. The calculation formula and definitions of brittleness used in this study are formulated as follows:

$$
\begin{gathered}
E=\frac{\rho\left(3 \Delta t s^{2}-4 \Delta t c^{2}\right)}{\Delta t s^{2}\left(\Delta t s^{2}-\Delta t c^{2}\right)} \\
\mu=\frac{0.5 \Delta t s^{2}-\Delta t c^{2}}{\Delta t s^{2}-\Delta t c^{2}} \\
\mathrm{BI}=\left(0.5 \times \frac{E-E \min }{E \max -E \min }+0.5 \times \frac{\mu-\mu \max }{\mu \min -\mu \max }\right) \times 100
\end{gathered}
$$

where $E$ is Young's modulus, GPa; $\mu$ is Poisson's ratio, dimensionless; $\rho$ is the density, $\mathrm{g} / \mathrm{cm}^{3} ; \Delta t s$ is the transverse wave time difference, $\mu \mathrm{m} / \mathrm{s} ; \Delta t c$ is the longitudinal wave time difference, $\mu \mathrm{m} / \mathrm{s}$; BI is the coal brittleness index, dimensionless; $E_{\max }$ and $E_{\min }$ are the maximum and minimum values of Young's modulus in a certain coal seam section in a certain block, GPa; and $\mu_{\max }$ and $\mu_{\min }$ are the maximum and minimum values of Poisson's ratio in a certain coal seam section in a certain block, dimensionless.

According to the statistics of elastic parameters of coal reservoirs in Mabidong block, the $\mu_{\max }$ and $\mu_{\min }$ of coal used in the normalization of brittleness index calculation are $0.3 \mathrm{GPa}$ and $0.2 \mathrm{GPa}$, and the $E_{\max }$ and $E_{\min }$ are $0.9 \mathrm{GPa}$ and $0.3 \mathrm{GPa}$ in this study.

2.2. Research Processes and Data Source. The overall research approach of this study is to use the elastic parameter method to calculate the coal brittleness index and combine the coal core analysis data to find out the influencing factors of the coal brittleness index reservoirs. The specific research process is detailed as follows: (1) Based on the core test data of CBM exploration wells in the Mabidong block, the vitrinite reflectance, macerals, and industrial analysis data of the tested coal samples were obtained. (2) Based on core photograph features corresponding to the depth of coal samples, the coalbody structure types of the corresponding coal seam were qualitatively determined. (3) Through the process of core true depth determination, the density logging parameters
TABLE 3: Mechanical parameters of No. 3 and No. 15 coal seams in the Mabidong block.

\begin{tabular}{lccc}
\hline $\begin{array}{l}\text { Coal-body } \\
\text { structure }\end{array}$ & $\begin{array}{c}\text { Coal } \\
\text { seam }\end{array}$ & $\begin{array}{c}\text { Modulus of } \\
\text { elasticity }\end{array}$ & $\begin{array}{c}\text { Poisson's } \\
\text { ratio }\end{array}$ \\
\hline Primary structure & No. 3 & 0.593 & 0.2269 \\
No. 15 & 0.660 & 0.2312 \\
Cataclastic & No. 3 & 0.635 & 0.2335 \\
structure & No. 15 & 0.610 & 0.2300 \\
Granulate & No. 3 & 0.715 & 0.2279 \\
structure & No. 15 & 0.741 & 0.2305 \\
\hline
\end{tabular}

(density logging value) and array acoustic logging parameters (transverse wave time difference and longitudinal wave time difference) corresponding to the sampling depth of core were obtained, and then, the coal brittleness index was obtained by elastic parameter method. (4) The influence of the coal-body structure and mechanical parameters on the coal brittleness index was analyzed. (5) The influence of coal quality parameters on the brittleness index is analyzed.

In this study, all the data of array acoustic logging, density logging, coal maceral composition, and coal quality parameters were approved and obtained from the field and laboratory test report of Huabei Oilfield Company of PetroChina. There are 9 wells with data from No. 3 coal seam and 6 wells with data from No. 15 coal seam.

\section{Geological Setting}

The Mabidong block is located in the southwest of Qinshui Basin, Shanxi Province, North China. The main structures in this block include the Qinshui synclinorium with NNEtrending and a series of associated NNE-trending normal faults [20]. According to the direction perpendicular to the synclinorium structural line strike, Mabidong block can be roughly divided into three tectonic units, and they are the western slope zone, the central trough zone and the eastern slope zone (Figure 1). The structure of the west wing is simple, and it is a monocline dipping toward southeast. The faults in this area are mostly small ones with short extension distance and the NNE strike. Compared with the west wing, the overall structure of the east wing is more complex, with more developed faults, generally smaller fault spacing, steeper occurrence, and shorter extension length. The results of structural interpretation show that the central and northern part of the block is relatively simple in structure, with large buried depth and good preservation conditions, and is a sweet spot for further CBM exploration.

The main coal-bearing strata in the block are Taiyuan Formation and Shanxi Formation in the CarboniferousPermian. The No. 3 coal seam in Shanxi Formation and No. 15 coal seam in Taiyuan Formation are the target strata of CBM development (Figure 2). The burial depth of No. 3 coal seam in the block is $860 \sim 1420 \mathrm{~m}$. The burial depth is shallow in the west and deep in the east, and the thickness is $4.6 \sim 8.0 \mathrm{~m}$ with an average of $6.2 \mathrm{~m}$. The maximum reflectance of vitrinite of No. 3 coal ranges from $2.61 \%$ to $3.36 \%$, with an average of $2.96 \%$. The No. 3 coal belongs to 


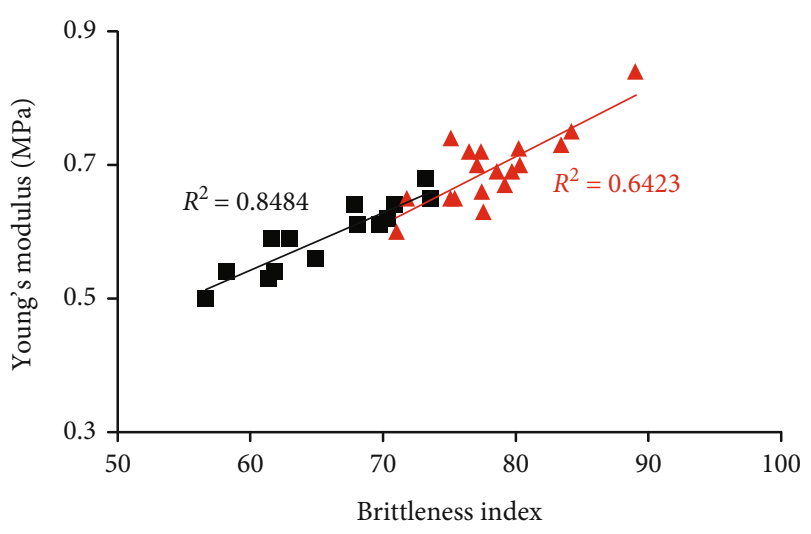

- Primary structure

A Cataclastic - granular structure

(a)

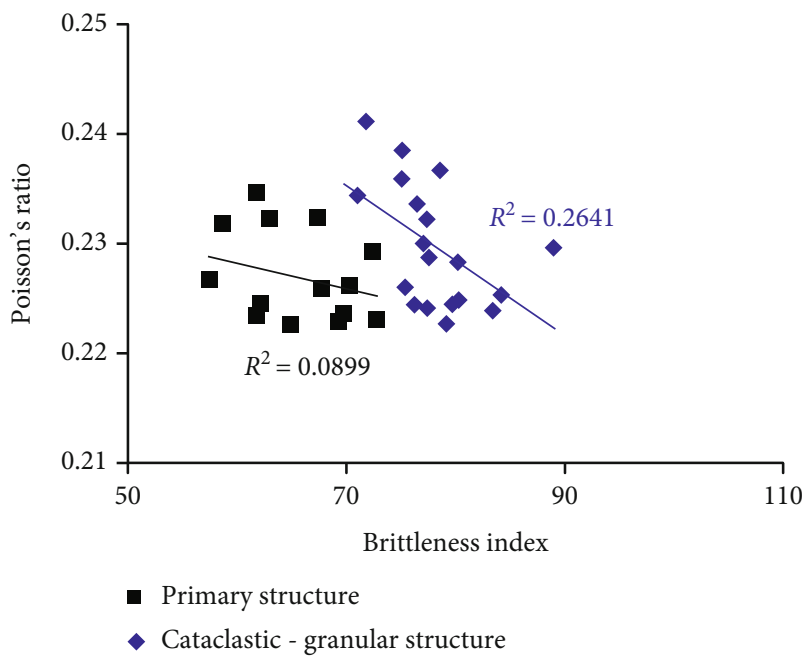

(c)

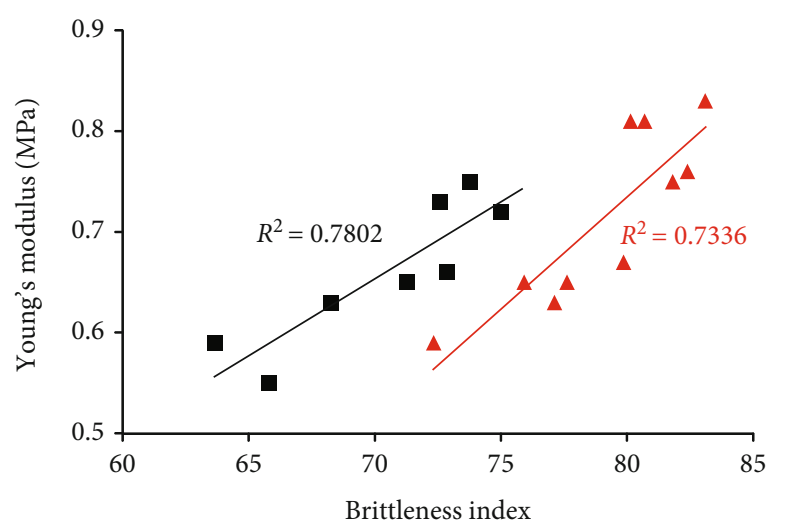

- Primary structure

A Cataclastic - granular structure

(b)

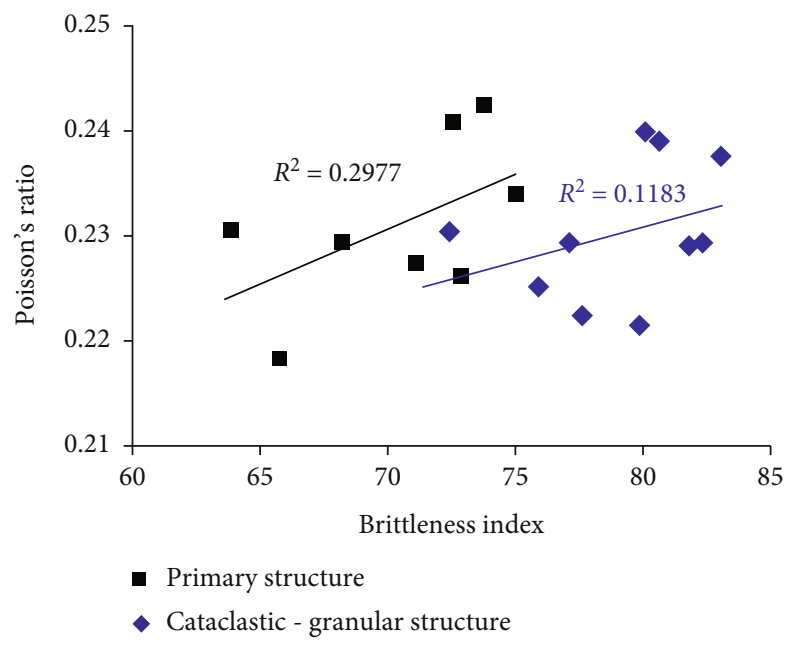

(d)

FIGURE 3: Relationship between mechanical parameters and the brittleness index of No. 3 and No. 15 coal: (a, c) No. 3 coal and (b, d) No. 15 coal.

anthracite. The burial depth of No. 15 coal seam is $980 \sim 1520 \mathrm{~m}$, about $100 \mathrm{~m}$ deeper than No. 3 coal seam. The burial depth trend is the same as No. 3 coal seam, shallow in the west and deep in the east. The thickness is mostly between 3.5 and $5.5 \mathrm{~m}$, with an average of $5.1 \mathrm{~m}$. The maximum reflectance of vitrinite of No. 15 coal ranges from $2.65 \%$ to $2.71 \%$, with an average of $2.68 \%$. The No. 15 coal also belongs to anthracite.

\section{Influencing Factors of Coal Reservoir Brittleness Index in Mabidong Block}

4.1. Relationship between Coal-Body Structure and Brittleness Index. The coal-body structure has great influence on the physical properties of coal reservoir properties [21, 22]. Due to the complex structural conditions (Figure 1), the tectonic coal is relatively developed in the Mabidong block. According to the characteristics of core shape, photograph, and the description of core characteristics (macrostructure and fracture), the coal core samples are divided into primary struc- ture coal, cataclastic structure coal, and granular structure coal (Table 1). The primary structure coal retains the original sedimentary structure characteristics, while the cataclastic structure coal and granulate structure coal were affected by the Indosinian Movement, Yanshan Movement, and Himalayan Movement and were strongly compressed, uplifted, and eroded. The degree of fragmentation of the cataclastic structure coal is larger than that of the primary structure coal, and the degree of fragmentation of granulate structure coal is the largest.

According to the density logging and array sonic logging data of CBM wells in the Mabidong block, the mechanical parameters are obtained, and the brittleness indexes are calculated according to the mechanical parameters. The brittleness indexes are compared with the coal-body structure types of drilling core samples. The relationship between the coalbody structure and brittleness index is studied and classified statistic (Table 2). The calculation results show that the average interval of the coal brittleness index of the primary structural coal, cataclastic structural coal, and granulate structural 
coal is $63.3-71.48,73.01-74.85$, and 77.41-82.77, respectively. It reveals that, according to the coal-body structure, the order of the coal brittleness index is primary structural coal $<$ cataclastic structural coal < granulate structural coal (Table 2). The results are consistent with previous studies $[15,16]$. It reveals that as the brittleness index generally is increasing, the degree of coal fragmentation increases. The reason may lie in the influence of Young's modulus. Previous studies have shown that Young's modulus of coal is closely related to density, porosity, and effective stress of the coal $[23,24]$. The Mabidong block is located in the core of syncline of Qinshui Basin, and the regional tectonic stress field is dominated by compression stress. Therefore, in the process of tectonic coal formation, the pores and fractures in coal seams were compressed and closed, the porosity decreases, and Young's modulus increases. There are a certain crossover and overlap between the brittleness indexes of different coal-body structures, which are affected by the characteristics of coal seam structure, heterogeneity, resolution of logging tools, continuity of logging response values, well bore, well section, and roof and floor lithology [15].

\subsection{Influence of Mechanical Parameters on Coal Brittleness} Index. The main mechanical parameters that affect the coal brittleness index are Young's modulus and Poisson's ratio. The relevant parameters based on statistics are shown in Table 3. In the study area, Young's modulus of granulate structure coal is relatively high, and Poisson's ratio of cataclastic structure coal is relatively high. Young's modulus and Poisson's ratio of No. 15 primary structure coal are both greater than that of No. 3 primary structure. The possible reason is that in the deeper coal-forming and water-covered environment of No. 15 coal, the gelation of peat is more thorough, and there are more homogeneous vitrinite and matrix vitrinite content [25].

The correlation among the brittleness index, Young's modulus, and Poisson's ratio of No. 3 coal seam and No. 15 coal seam is shown in Figure 3. Young's modulus has a good positive correlation with the brittleness index. Young's modulus and the brittleness index of primary structure coal of No. 3 coal seam have the best correlation, followed by the primary structure coal of No. 15 coal seam (Figures 3(a) and $3(b)$ ). This is because the coal body of the primary structural coal is complete and its mechanical properties are more stable. Poisson's ratio and brittleness index are negatively correlated in No. 3 coal seam (Figure 3(c)) but are positive correlated in No. 15 coal seam (Figure 3(d)). The correlation coefficient between Poisson's ratio and the coal brittleness index is small. The difference in the correlation between the same mechanical parameter and the brittleness index is comprehensively affected by the coal-body structure, coal macerals, and coal quality parameters.

4.3. Influence of Macerals on Coal Brittleness Index. The brittleness index is a complex function of lithology, composition, temperature, and porosity [26]. Due to the different mechanical properties of different coal macerals, the composition of coal macerals has an important influence on the coal brittleness index. According to some of the measurement results of
TABLE 4: Statistics of macerals of coal with different coal-body structures in the Mabidong block.

\begin{tabular}{lcccc}
\hline $\begin{array}{l}\text { Coal-body } \\
\text { structure }\end{array}$ & $\begin{array}{c}\text { Coal } \\
\text { seam }\end{array}$ & $\begin{array}{c}\text { Vitrinite } \\
(\%)\end{array}$ & $\begin{array}{c}\text { Inertinite } \\
(\%)\end{array}$ & $\begin{array}{c}\text { Minerals } \\
(\%)\end{array}$ \\
\hline Primary & No. 3 & 82.65 & 17.3 & 4.80 \\
structure & No. 15 & 91.66 & 9.00 & 4.37 \\
& Average & 84.49 & 14.81 & 4.50 \\
Cataclastic & No. 3 & 81.01 & 18.99 & 3.67 \\
structure & No. 15 & 83.94 & 16.06 & 6.40 \\
& Average & 81.98 & 18.02 & 4.58 \\
Granulate & No. 3 & 78.21 & 21.79 & 4.32 \\
structure & No. 15 & 91.95 & 8.05 & 6.96 \\
& Average & 83.94 & 16.06 & 5.86 \\
\hline
\end{tabular}

coal macerals of 13 wells (15-layer coal seams) in the Mabidong block, the macerals and the brittleness index data of coal with different coal-body structures are obtained.

As shown in Table 4, the macerals of high metamorphic anthracite is mainly vitrinite. The vitrinite content and the mineral content of No. 15 coal seam is generally higher than that of No. 3 coal seam, and the inertite content is lower than that of No. 3 coal seam, which is caused by the deep water covering of the coal formation environment of No. 15 coal seam [25]. The average vitrinite content of primary structure, cataclastic structure, and granulate structure coals is $84.49 \%$, $81.98 \%$, and $83.94 \%$. The average inertinite content of primary structure, cataclastic structure, and granulate structure coals is $14.81 \%, 18.02 \%$, and $16.06 \%$. The average mineral content of primary structure, cataclastic structure, and granulate structure coals is $4.50 \%, 4.58 \%$, and $5.86 \%$. There is no exinite in coal of this block, because aliphatic components in the exinite will be converted into gaseous hydrocarbons in the middle to high coalification stage.

The brittleness index varies with changes in the maceral and microlithotype composition of coal. In the Mabidong block, the vitrinite content is positively correlated with the coal brittleness index (Figure 4(a)), while the inertite content is negatively correlated with the coal brittleness index (Figure 4(b)). The correlation between the brittleness index and macerals in the primary structure coal is better than that of the cataclastic and granulate structure coal (Figures 4(a) and 4(b)). Previous studies have shown that different components of coal have different effects on brittleness, grindability, and breakability of coal, and the brittleness of the coal structure rather than its hardness dominates coal grindability [19, $27,28]$. The vitrinite is the brittleness component in coal, and the inertinite is the hardness component in coal. As a result, for the primary structure coal, the coal brittleness index is positively correlated with the vitrinite content, but negatively correlated with the inertinite content obviously. The correlations between the mineral and brittleness index of different coal-body structures are poor (Figure 4(c)). The main reason is that the content of minerals in coal is relatively low, and it is easily affected by the deformation of coal structure. Nevertheless, it can be seen that there is a certain positive correlation between the brittleness index and mineral content in primary structural coal (Figure 4(c)). Because Young's 


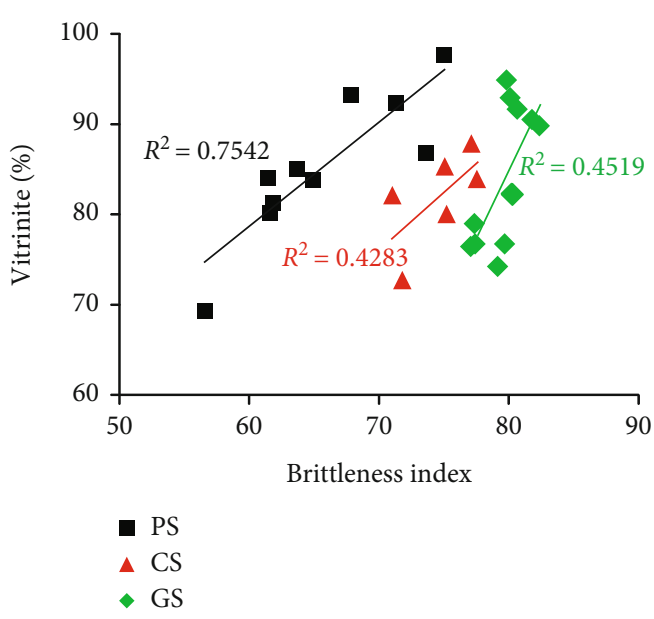

(a)

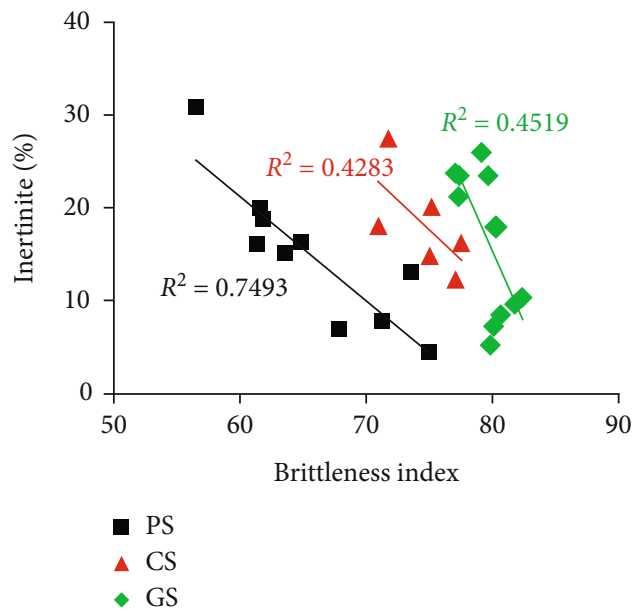

(b)

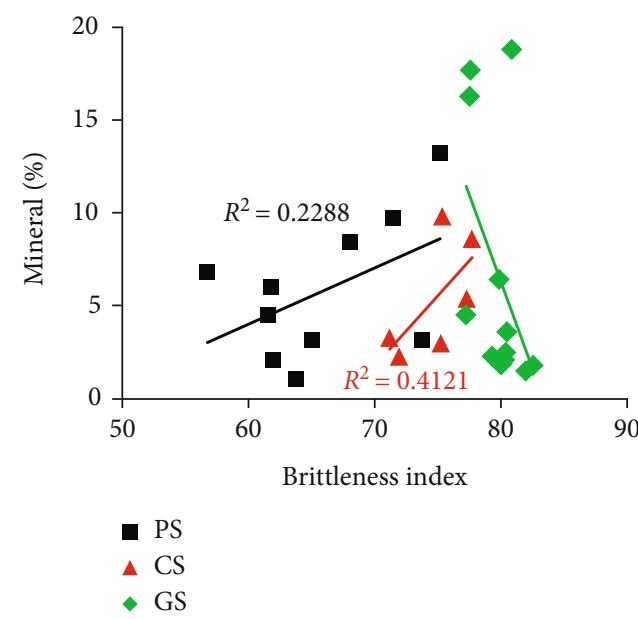

(c)

FIGURE 4: Relationship between microscopic composition, brittleness index, and Young's modulus. PS is primary structure, CS is cataclastic structure, and GS is granulate structure.

modulus of inorganic minerals is generally higher than that of organic coal, the presence of inorganic minerals can increase Young's modulus of the coal.

\subsection{Influence of Coal Quality Parameters on Coal Brittleness} Index. The proximate analysis of coal is the most common experimental analysis method in coal quality analysis. The proximate analysis indexes of coal include ash, moisture, volatile, and fixed carbon. Based on the proximate analysis of coal samples from CBM wells, coal quality parameters of No. 3 and No. 15 coal seams in the Mabidong block are obtained. As shown in Table 5, the coal quality parameters of No. 3 and No. 15 coal seams have little differences. The moisture content of No. 15 coal seam is less than that of No. 3 coal seam, the volatile of primary structural coal and cataclastic structural coal of No. 15 coal seam is both larger than that of No. 3 coal seam, and the volatile of granulate structural coal are smaller than that of No. 3 coal seam. The ash content of granular structure coal is the highest, which is consistent with the highest mineral content of granular structure coal.
The correlation between coal quality parameters and brittleness index data of different coal-body structure in Mabidong block of Qinshui Basin is obtained by statistical analysis (Figure 5). It is obvious that the correlation between the brittleness index and coal quality parameters is obviously affected by the coal-body structure, showing different correlation rules. For the primary structure coal and cataclastic structure coal, the content of ash and volatile is positively correlated with the brittleness index, while the content of fixed carbon is negatively correlated with the brittleness index. However, for the granulate structure coal, these correlation rules are just opposite (Figures 5(a), 5(b), and 5(d)). The positive correlation between ash content and coal brittleness is consistent with the results in Figure 4(a), because the presence of inorganic minerals increases Young's modulus of the coal [24]. The correlation between the brittleness index and coal quality parameters in the primary structure coal is significantly better than that of the cataclastic and granulate structure coals. This phenomenon reveals that the influence of the coal-body structure on the brittleness index is higher than that of coal quality parameters. The higher the failure 
TABLE 5: Coal quality parameters of No. 3 and No. 15 coal seams in the Mabidong block (air-dried basis).

\begin{tabular}{|c|c|c|c|c|c|}
\hline Coal-body structure & Coal seam & Moisture (\%) & Ash (\%) & Volatile (\%) & Fixed carbon (\%) \\
\hline \multirow{3}{*}{ Primary structure } & No. 3 & 0.82 & 10.026 & 8.26 & 69.75 \\
\hline & No. 15 & 0.807 & 19.52 & 9.9 & 80.91 \\
\hline & Average & 0.811 & 12.875 & 8.75 & 77.56 \\
\hline \multirow{3}{*}{ Cataclastic structure } & No. 3 & 0.98 & 10.505 & 8.39 & 79.545 \\
\hline & No. 15 & 0.125 & 11.835 & 8.495 & 80.125 \\
\hline & Average & 0.695 & 10.948 & 8.425 & 79.932 \\
\hline \multirow{3}{*}{ Granulate structure } & No. 3 & 0.978 & 17.57 & 9.96 & 71.486 \\
\hline & No. 15 & 0.954 & 12.552 & 8.89 & 84.183 \\
\hline & Average & 0.968 & 15.48 & 9.52 & 76.103 \\
\hline
\end{tabular}

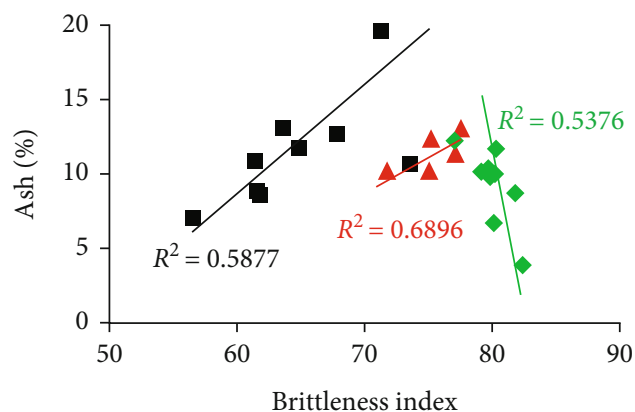

- PS

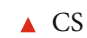

- GS

(a)

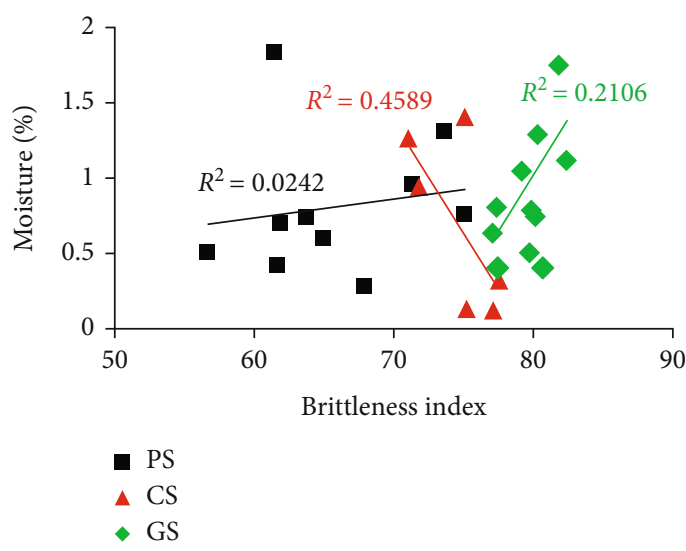

(c)

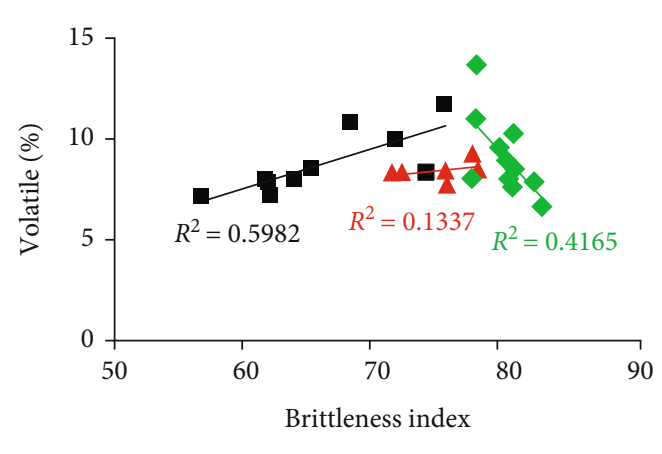

- PS

$\triangle \mathrm{CS}$

- GS

(b)

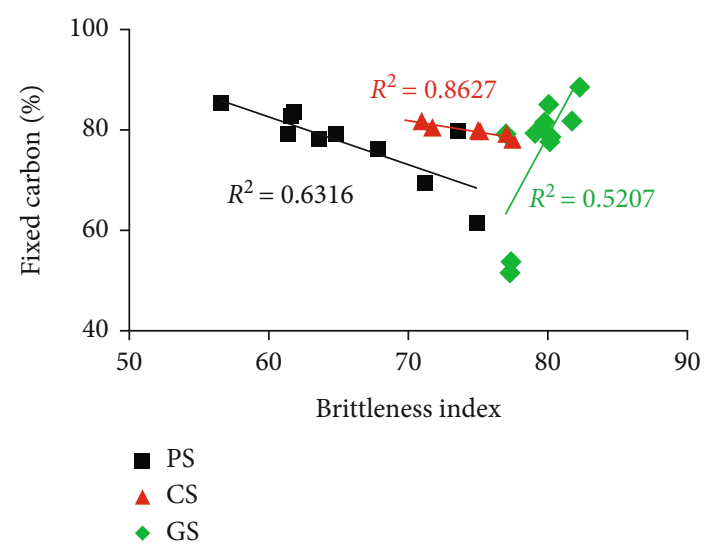

(d)

FIGURE 5: Relationship between the coal quality index and brittleness index. PS is primary structure, CS is cataclastic structure, and GS is granulate structure.

degree of coal-body structure, the more complex the factors affecting the coal brittleness index. The correlations between moisture and the brittleness index of different coal-body structures are poor (Figure 5(c)). The reason is that the differences of moisture (intrinsic water) in the coal seam within the same block are very tiny, and the brittleness index calculated by logging may be more affected by external water in coal fissures.

\section{Conclusion}

(1) The calculation results of coal brittleness by elastic parameter method show that, according to the coalbody structure, the order of the coal brittleness index is primary structural coal $<$ cataclastic structural coal $<$ granulate structural coal. This may be because under the background of compressive stress field, 
pores and fractures in coal seam are compressed and closed, porosity decreases, and Young's modulus increases. There is a good correlation between mechanical parameters and the coal brittleness index, and the brittleness index is more affected by Young's modulus than Poisson's ratio

(2) Coal macerals are closely related to Young's modulus and Poisson's ratio, which can influence the brittleness of coal. The vitrinite content is positively correlated with the brittleness index, while the content of inertinite is negatively correlated in different types of coal-body structures. The vitrinite and inertinite content in primary structure coal has the best correlation with brittleness index. In addition, the mineral content of coal also affects the brittleness of coal in different degrees

(3) For the primary and cataclastic structure coals, the ash and volatile is positively correlated with the brittleness index. However, for the granulate structure coal, these correlation rules are just opposite. The correlation of the brittleness index and coal quality parameters in the primary structure coal is significantly better than that of cataclastic and granulate structure coals. It reveals that the influence of the coal-body structure on the brittleness index is higher than that of coal quality parameters

(4) The mechanical parameters, macerals, and coal quality index of coal are closely related to each other, and together affect the coal brittleness index. This study can provide a useful reference for brittleness characteristics and the relationship between brittleness index and composition of high-rank coal with different coal-body structures. The results are helpful to guide the application of the coal brittleness index and coal-body structure prediction in fracturing of CBM wells. More research on the influencing mechanism of microstructure on the coal brittleness index needs to be carried out in the future

\section{Data Availability}

All data are derived from field logging and sampling test data from CBM Wells of Huabei Oilfield Company of PetroChina, which are given in the article and described in Acknowledgements.

\section{Conflicts of Interest}

The authors declare that they have no conflicts of interest.

\section{Acknowledgments}

We are grateful to Huabei Oilfield Company of PetroChina and Dr. Qianhua Xiao from Chongqing University of Science \& Technology for providing some useful data and suggestion for this study. This work was funded by the National Natural Science Foundation of China (NSFC) Project (41702175,
U1910204), National Science and Technology Major Project (Oil \& Gas) (2017ZX05064, 2016ZX05065), and Research project of China United Coalbed Methane Co., Ltd (ZZGSSAYJPYTH2020-300).

\section{References}

[1] J. Lai, G. W. Wang, Z. Y. Fan et al., "Research progress on brittleness index logging evaluation methods for unconventional oil and gas reservoirs," Petroleum Science Bulletin, vol. 1, no. 3, pp. 2096-1693, 2016.

[2] B. Liu, S. Wang, X. Ke et al., "Mechanical characteristics and factors controlling brittleness of organic-rich continental shales," Journal of Petroleum Science and Engineering, vol. 194, article 107464, 2020.

[3] Y. Li, J. H. Yang, Z. J. Pan, and W. S. Tong, "Nanoscale pore structure and mechanical property analysis of coal: an insight combining AFM and SEM images," Fuel, vol. 260, article 116352, 2020.

[4] S. P. Singh, "Brittleness and the mechanical winning of coal," Mining Science and Technology, vol. 3, no. 3, pp. 173-180, 1986.

[5] R. Altindag, "Assessment of some brittleness indexes in rockdrilling efficiency," Rock Mechanics and Rock Engineering, vol. 43, no. 3, pp. 361-370, 2010.

[6] R. Feng, Y. Zhang, A. Rezagholilou, H. Roshan, and M. Sarmadivaleh, "Brittleness Index: from conventional to hydraulic fracturing energy model," Rock Mechanics and Rock Engineering, vol. 53, no. 2, pp. 739-753, 2020.

[7] V. Hucka and B. Das, "Brittleness determination of rocks by different methods," International Journal of Rock Mechanics and Mining Sciences and Geomechanics Abstracts, vol. 11, no. 10, pp. 389-392, 1974.

[8] B. R. Law and D. B. Marshal, "Residual stress effects in failure from flaws," Journal of the American Ceramic Society, vol. 62, no. 1-2, pp. 106-108, 1979.

[9] R. Altindag, "Correlation of specific energy with rock brittleness concepts on rock cutting," Journal of the South African Institute of Mining and Metallurgy, vol. 103, no. 3, pp. 163171, 2003.

[10] D. M. Jarvie, R. J. Hill, T. E. Ruble, and R. M. Pollastro, "Unconventional shale-gas systems: the Mississippian Barnett Shale of North-Central Texas as one model for thermogenic shale-gas assessment," AAPG Bulletin, vol. 91, no. 4, pp. 475-499, 2007.

[11] R. Rickman, M. J. Mullen, J. E. Petre, B. Grieser, and D. Kundert, "A practical use of shale petrophysics for stimulation design optimization: all shale plays are not clones of the Barnett Shale," in SPE Annual Technical Conference \& Exhibition, pp. 21-24, Denver, Colorado, USA, September, 2008.

[12] X. H. Zhang, X. C. Zou, H. Y. Zhao, F. Li, and L. M. Qin, "A new method for evaluating shale brittleness using $\mathrm{X}$ fluorescence element logging data," Petroleum Drilling Technology, vol. 40, no. 5, pp. 96-99, 2012.

[13] H. Wang and J. Tang, "Research on influencing factors and evaluation methods of shale gas reservoir brittleness," in China Earth Sciences Joint Academic Annual Conference, vol. 27, pp. 56-57, Beijing, China, 2016.

[14] Y. J. Lu, Z. Z. Yang, V. V. Shelepov, J. X. Han, X. G. Li, and W. Han, "Evaluation and research of brittleness on simulated 
reservoir volume in coal," Oil and Gas Reservoir Evaluation and Development, vol. 8, no. 1, pp. 64-70, 2018.

[15] L. Ai, M. S. Zhou, J. Zhang, X. Liang, B. W. Qian, and D. R. Liu, "Logging quantitative identification of coal-body structure based on coal brittleness index," Lithologic Reservoirs, vol. 29, no. 2, pp. 139-144, 2017.

[16] J. Zhang, L. H. Fan, J. Mei, N. N. Feng, and J. Liu, “Application of logging technology in the identification of coal and rock structure in Fanzhuang area," China Coalbed Methane, vol. 14, no. 3, pp. 12-16, 2017.

[17] H. B. Wu, P. S. Zhang, S. H. Dong, Y. P. Huang, and M. Zhang, "Brittleness index analysis of coal samples," Acta Geophysica, vol. 67, no. 3, pp. 789-797, 2019.

[18] J. Zhang, C. Ai, Y. W. Li, M. G. Che, R. Gao, and J. Zeng, "Energy-based brittleness index and acoustic emission characteristics of anisotropic coal under triaxial stress condition," Rock Mechanics and Rock Engineering, vol. 51, no. 11, pp. 3343-3360, 2018.

[19] T. OKI, J. TANAKA, and T. HARADA, "Cause of coal grindability correlation of coal rank, maceral composition, hardness, and brittleness," Shigen to Sozai, vol. 112, no. 1, pp. 3742, 1996.

[20] Y. H. Yang, Y. T. Wang, L. W. Chen et al., "Optimization technology of efficient CBM productivity areas in QinnanxiMabidong Block, Qinshui Basin, Shanxi, China," Journal of China Coal Society, vol. 43, no. 6, pp. 1620-1626, 2018.

[21] X. D. Zhang, Z. G. Du, and P. P. Li, "Physical characteristics of high-rank coal reservoirs in different coal-body structures and the mechanism of coalbed methane production," Science China Earth Sciences, vol. 60, no. 2, pp. 246-255, 2017.

[22] Y. Cheng and Z. Pan, "Reservoir properties of Chinese tectonic coal: a review," Fuel, vol. 260, article 116350, 2020.

[23] J. Q. Li, D. M. Liu, S. F. Lu, H. T. Xue, and W. H. Li, "Experimental study on Young's modulus of medium and high rank coals and its influencing factors," Coal Science and Technology, vol. 44, no. 1, pp. 102-108, 2016.

[24] Q. Li, J. Chen, and J. J. He, "Physical properties, vitrinite reflectance, and microstructure of coal, Taiyuan Formation, Qinshui Basin, China," Applied Geophysics, vol. 14, no. 4, pp. 480-491, 2017.

[25] H. Liu, W. H. Huang, X. X. Lu, S. P. Liu, and J. L. Luo, "Research on the control of coal micro-coal composition on micro-cracks of Qinnan no.3 coal seam and no.15 coal seam," Resources and Industry, vol. 14, no. 4, pp. 81-87, 2012.

[26] M. Heidari, G. R. Khanlari, M. Torabi-Kaveh, S. Kargarian, and S. Saneie, "Effect of porosity on rock brittleness," Rock Mechanics and Rock Engineering, vol. 47, no. 2, pp. 785-790, 2014.

[27] A. E. Hansen and J. C. Hower, "Notes on the relationship between microlithotype composition and hardgrove grindability index for rank suites of eastern Kentucky (central Appalachian) coals," International Journal of Coal Geology, vol. 131, pp. 109-112, 2014.

[28] C. L. Hou, B. Jiang, H. W. Liu, Y. Song, and S. C. Xu, “The differences of nanoscale mechanical properties among coal maceral groups," Journal of Natural Gas Science and Engineering, vol. 80, article 103394, 2020. 